\title{
Preliminary study of the antimicrobial activity of Mentha $x$ villosa Hudson essential oil, rotundifolone and its analogues
}

\author{
Thúlio. A. Arruda ${ }^{1 *}$, Rossana M.P. Antunes ${ }^{1}$ Raissa M.R. Catão ${ }^{1}$ Edeltrudes O. Lima ${ }^{2}$, \\ Damião P. Sousa ${ }^{2}$, Xirley P. Nunes ${ }^{2}$, Maria S.V. Pereira ${ }^{3}$, José M. Barbosa-Filho ${ }^{2}$, \\ Emidio V. L. da Cunha ${ }^{1,2}$ \\ ${ }^{1}$ Departamento de Farmácia, Universidade Estadual da Paraíba, Campus Universitário, Bodocongó, 58100-000, \\ Campina Grande, PB, Brazil, \\ ${ }^{2}$ Laboratório de Tecnologia Farmacêutica, Universidade Federal da Paraíba, Caixa Postal 5009, 58051-970, João \\ Pessoa, PB, Brazil, \\ ${ }^{3}$ Laboratório de Biologia Molecular, Universidade Federal da Paraíba, 58051-970, \\ João Pessoa, PB, Brazil
}

\begin{abstract}
RESUMO: "Estudo preliminar da atividade antimicrobiana do óleo essencial de Mentha $\boldsymbol{x}$ villosa Hudson, rotundifolona e seus análogos". Os óleos essenciais apresentam atividade antimicrobiana contra uma variedade de bactérias e fungos, incluindo espécies resistentes a antibióticos e antimicóticos. Neste contexto, este trabalho objetiva a avaliação da atividade de antimicrobiana do óleo essencial de Mentha $x$ villosa Hudson (hortelã-da-folha-miúda) - seu componente majoritário (rotundifolona) e quatro análogos sintéticos da rotundifolona (epóxilimoneno epóxi-pulegona, epóxi-carvona e (+)-pulegona) frente a cepas padrão de Staphylococcus aureus ATCC 25923, Escherichia coli ATCC 25922 Pseudomonas aeruginosa ATCC 27853, Candida albicans ATCC 76645 e uma cepa de Staphylococcus aureus meticilina - resistente MRSA (171c) de clínica humana. Como método, foi utilizada a difusão em placas com médio sólido. Os resultados mostraram que o óleo de Mentha $x$ villosa, rotundifolona, epóxi-limoneno e (+)-pulegona, são semelhante em função da atividade antimicrobiana para as cepas de S. aureus e C.albicans testadas. Todos os produtos apresentaram potencial antimicrobiano com atividade antibacteriana para S. aureus ATCC 25923 e atividade antifúngica para C. albicans ATCC 76645. Nenhum dos produtos apresentou atividade antimicrobiana para as cepas de E. coli ATCC $25922 \mathrm{e}$ P. aeruginosa ATCC 27853, representantes das bactérias Gram negativas.
\end{abstract}

Unitermos: Mentha x villosa, Labiatae, óleo essencial, rotundifolona, atividade antimicrobiana.

\begin{abstract}
Essential oils present antimicrobial activity against a variety of bacteria and yeasts, including species resistant to antibiotics and antifungicals. In this context, this work aims at the evaluation of the antimicrobial activity of the essential oil of Mentha $x$ villosa Hudson ("hortelã da folha miúda"), its major component (rotundifolone) and four similar analogues of rotundifolone (limonene oxide, pulegone oxide, carvone epoxide and (+)-pulegone) against strain standards of Staphylococcus aureus ATCC 25923, E. coli ATCC 25922, Pseudomona aeruginosa ATCC 27853, Candida albicans ATCC 76645 and one strain of meticilin - resistant Staphylococcus aureus MRSA (171c) from human clinic. The method of the diffusion in plates with solid medium was used. The results showed that the oil of Mentha $x$ villosa, rotundifolone, limonene oxide and (+)pulegone, are similar regarding the antimicrobial activity against the tested strains of $S$. aureus and $C$. albicans. All of the products present antimocrobial potential with antibacterial activity for S. aureus ATCC 25923 and antifungal activity for C. albicans ATCC 76645. None of the products presented antimicrobial activity for the strains of E. coli ATCC 25922 and P. aeruginosa ATCC 27853, representatives of the Gram negative bacteria.
\end{abstract}

Keywords: Mentha $x$ villosa, Labiatae, essential oil, rotundifolone, antimicrobial activity.

\section{INTRODUCTION}

The use of the plants with medicinal purposes is as old as humanity's history. People, throughout the time used plants as a form to obtain relief of the symptoms or the cure of their diseases. Either as a religious, or as a healing process, they highlighted the aromatic plants holders of essential oils, whose components and biological activities became objective of several researches in the last years (Cowan, 1999; Hoareau; Da Silva, 2001; Agostini et al., 2005; Silva-Santos et al., 2004; Bieski, 2005).

Essential oils present antimicrobial activity against a variety of bacteria and yeasts, including resistant species to antibiotics and antifungal agents (Carson et al., 1995; Duarte et al., 2004; Bertini et al., 2005; Oliveira et al., 2006; Lima et al., 2006). Composition of the essential 
oils can vary with the climate, geographical area, seasons, soil conditions, crop period and extraction technique (Maciel et al., 2002; Bertini et al., 2005; Carvalho-Filho et al., 2006; Potzernheim et al., 2006).

Several species of mentha have been investigated because of the essential oil produced by their leaves (Hiruma, 1993; Monte et al., 2001; Gobert et al., 2002; Lorenzo et al., 2002; Marchese et al., 2005; Sartoratto et al., 2004; Bertini et al., 2005; Bieski, 2005). The genus Mentha, family Labiatae, of the subfamily Nepetoidae and of the tribe Mentheae, is composed by approximately, 25 species. Mentha $x$ villosa is an herb cultivated throughout Brazil and is used as traditional medicine in the treatment of amebiasis, giardiasis and schistosomiasis (Hiruma, 1993; Matos et al., 1999; Monte et al., 2001). The essential oil and rotundifolone from Mentha $x$ villosa showed vasorelaxant effect (Guedes et al., 2004a, Guedes 2004b).

No-rational use of antibiotics has been causing a series of problems for the enviroment and for the human beings, among which stands out the appearance of resistance. Since the beginning of the eighties it is observed that the antimicrobial agents number decreased considerably, while the resistance of the microorganisms to them has been growing in a fast way due to the development of new resistance mechanisms (MoelleringJr, 2000).

For this reason, this work aims at the evaluation of the antimicrobial activity of the essential oil of Mentha $x$ villosa ("hortelã da folha miúda"), its major component (rotundifolone) and four analogues of rotundifolone (limonene oxide, pulegone oxide, carvone epoxide and (+)-pulegone) against standards strain of Staphylococcus aureus ATCC 25923, Escherichia coli ATCC 25922, Pseudomona aeruginosa ATCC 27853 and one strain of Meticilin - Resistant Staphylococcus aureus - MRSA (171c) from human clinic.

\section{MATERIAL AND METHODS}

\section{Botanical material}

The collection of the leaves of Mentha $x$ villosa Hudson (approximately $2 \mathrm{~kg}$ ), was carried out in the morning in the Medicinal Plants' Garden of the Laboratorio de Tecnologia Farmacêutica of the Universidade Federal da Paraíba - LTF/UFPB ( $7^{\circ} 08^{\prime} 29^{\prime \prime} \mathrm{S}$, $34^{\circ} 50$ ' $\left.48^{\prime \prime} \mathrm{W}\right)$.

\section{Extraction of the essential oil}

The fresh leaves were subjected to steam distillation using a Clevenger apparatus (Wasicky, 1963). The extraction period lasted an average of six hours and an oil of yellowish coloration and characteristic odor was obtained.
Isolation of rotundifolone from the essential oil of Mentha $x$ villosa

The isolation and identification processes followed the methodology in described by Hiruma (1993) and Matos et al. (1999). The essential oil was submitted to preparative thin layer chromatography, using hexane as eluent. When the plates were exposed to UV light (254 $\mathrm{nm}$ ) it was possible to observe rotundifolone as the major component of the essential oil. Rotundifolone was removed of the chromatographic plates and later recovered of the silica-gel by extraction with chloroform.

\section{Rotundifolone analogues}

The substances limonene oxide (Thomas; Bessiere, 1989), pulegone oxide (Katsuhara, 1967), and carvone epoxide (Santos et al., 1997) were prepared as previously described. (+)-Pulegone was purchased from Aldrich.

\section{Microorganism strains}

Antimicrobial activity tests were carried ou against the bacteria Staphylococcus aureus ATCC 25923, Escherichia coli ATCC 25922, Pseudomona aeruginosa ATCC 27853 and one strain of MRSA (171c) from human clinic and the yeast Candida albicans ATCC 76645.

\section{Culture media}

Bacteria were assayed in Mueller-Hinton Agar (DIFCO Laboratories) and C. albicans on Sabouraud Dextrose Agar (DIFCO Laboratories).

\section{Diffusion method in plates with solid medium}

The method used was the diffusion in agar (Bauer et al., 1966) following the recommendations of the NCCLS (Nattional Commitee for Clinical Laboratory Standart).

\section{Inocula}

Starting from cultures maintained in Agar Mueller-Hinton, for 24 hours (Bacteria), to the temperature of $37{ }^{\circ} \mathrm{C}$ and $24-72 \mathrm{~h}$ (fungi) to the room temperature, the inoculate was prepared (Benoudia et al., 1988; Odds, 1989 ) and standardized in physiologic solution (chloride of sodium) to $0.85 \%$ sterile (Casals, 1979; Plempel, 1986). Initially, it was prepared a comparative solution with the one of sulfate of barium of the tube 0.5 of the McFarland and cellular counting in a Newbawer's camera. The suspension contained, approximately, $10^{6} \mathrm{UFC} / \mathrm{mL}$ (Casals, 1979; Drutz, 1987). The plates containing middle of culture, they were sowed with this inoculate with the aid of sterile swabs. 


\section{Evaluation of the antibacterial activity}

Approximately $20 \mathrm{~mL}$ of the culture medium was added to each disposable sterile plate $(90 \mathrm{~mm})$. After solidification, the inocula were dispersed in the surfaces, with the aid of a swab. Afterwards, cavities with $6 \mathrm{~mm}$ of diameter were made, where $50 \mu \mathrm{L}$ of each product were placed. The plates were incubated at $37^{\circ} \mathrm{C}$ for 24 hours. Each test was carried out in duplicate against each selected strain. The final result was obtained by calculating the arithmetic average of the diameter of the halos of inhibition in the two assays, being considered active against the strains in study, those which produced halos starting from $9 \mathrm{~mm}$ of diameter (Gundidza, 1986).

\section{RESULTS AND DISCUSSION}

The results obtained during the tests are presented in the table 1 .

Several studies indicate that the essential oils of the genus Mentha possess biological activity against several bacteria and yeast (Oumzil et al., 2002; Sartoratto et al., 2004; Mounchid et al., 2005). According to Ohno et al. (2003), there are differences in the activity of an oil to another or even of their subproducts, due to the structure activity relationship. Many of the oil components may possess the ability to break or to penetrate the lipid structure present in the Gram-negatives bacteria wall.

Table 1 shows the results found in this study, where one can observe that the essential oil of Menthax villosa, rotundifolone and their analogues did not present any inhibition of the growth on the samples of $E$. coli ATCC 25922 and P. aeruginosa ATCC 27853. (Figure $1)$

Regarding the strains of Staphylococcus aureus, it was observed that all of the tested substances presented antibacterial activity, characterized by the presence of zones of growth inhibition with diameters that varied from $9 \mathrm{~mm}$ (carvone epoxide) to $16 \mathrm{~mm}$ (Mentha $x$ villosa essential oil) for the strain $S$. aureus ATCC 25923, while limonene oxide and carvone epoxide did not present any activity against the studied strain (171c). This fact can be justified by the individual behavior of each strain and by the presence of different genes of plasmidial and/or cromossomial resistance that determine, besides the virulence factors, the resistance to the antimicrobian agents (Trabulsi, et al., 1999).

All of the products presented antifungal activity against the strain of Candida albicans ATCC 76645, developing halos of inhibition that varied from $15 \mathrm{~mm}$ (limonene oxide) to $18 \mathrm{~mm}$ (Mentha $x$ villosa and carvona epoxide).

The essential oil of Mentha $x$ villosa was the product that presented the largest zones of growth inhibition among the sensible strains. This happens, probably because the essential oils are composed by, several substances that can interact jointly in a synergic/ potential form, giving them strong antimicrobial activity (Carson et al., 1995; Mounchid et al., 2005). Other factor that should also be studied and considered is related to the diffusion ability of the tested product in the culture medium, which can favor in some situations, the diameter of the zones of growth inhibition.

The results of this preliminary study in relation to the antimicrobial structure-activity of rotundifolone and their analogues, showed that rotundifolone, pulegone oxide and $(+)$-pulegone presented similar antimicrobial activity, diverging discreetly just in relation to the size of the zones of growth inhibition, what may be considered irrelevant in function of the presence of activity proven by the existence of growth inhibition zones $\leq 10 \mathrm{~mm}$ (Gundiza, 1986).

The presence of a ketone ring in the molecule carvone epoxide in a different position of the original molecule rotundifolone, as well as the presence of a single epoxide group and the absence of the ketone in the molecule of limonene oxide can be factors that interfere with the antimicrobial activity, when appraised in function of the size of the growth inhibition zones. However, the antimicrobial activity of a product can not be determined only in function of the presence/absence of zones of growth inhibition, or also as a function of its size. Other microbiologic subsequent studies such as evaluation of the effect of those products on the microbial kinetics, are being carried out and they will probably help to elucidate the real antimicrobial potency of these products, and also define the effects as bactericide/fungicide or bacteriostatic/ fungistatic.

Table 1. Effects of the essencial oil of Mentha $x$ villosa Hudson, rotundifolone and its analogues against the tested strains of the microorganisms.

\begin{tabular}{l|ccccc}
\hline \multirow{2}{*}{$\begin{array}{c}\text { Substances } \\
(200 \mu \mathrm{g} . \mathrm{mL})\end{array}$} & \multicolumn{4}{|c}{ Tested microrganisms/diameters of inhibition zones (mm) } \\
\cline { 2 - 6 } \multicolumn{1}{c|}{$\begin{array}{c}\text { S. aureus } \\
\text { ATCC } 25923\end{array}$} & $\begin{array}{c}\text { S. aureus } \\
\text { MRSA (171c) }\end{array}$ & $\begin{array}{c}\text { E. coli } \\
\text { ATCC 25922 }\end{array}$ & $\begin{array}{c}\text { P. aeruginosa } \\
\text { ATCC 27853 }\end{array}$ & $\begin{array}{c}\text { C. albicans } \\
\text { ATCC 76645 }\end{array}$ \\
\hline Mentha villosa oil & 16 & 13 & 0 & 0 & 18 \\
Rotundifolone & 14 & 12 & 0 & 0 & 17 \\
Limonene oxide & 9 & 0 & 0 & 0 & 15 \\
Pulegone oxide & 12 & 12 & 0 & 0 & 17 \\
Carvone epoxide & 9 & 0 & 0 & 0 & 18 \\
(+)-Pulegone & 11 & 12 & & & 16 \\
\hline
\end{tabular}


<smiles>CC(C)=C1CCC2(C)OC2C1=O</smiles>

Rotundifolone<smiles>C=C(C)C1CCC2(C)OC2C1</smiles>

Limonene oxide<smiles>CC(C)=C1CCC(C)CC1=O</smiles>

(+)-Pulegone<smiles>C[C@H]1CCC2(OC2(C)C)C(=O)C1</smiles>

Pulegone oxide<smiles>C=C(C)C1CC(=O)[C@]2(C)O[C@H]2C1</smiles>

Carvone epoxide

Figure 1. Compounds used in this study.

\section{CONCLUSION}

According the found results, it can be concluded that the essential oil of Mentha $x$ villosa, rotundifolone, limonene oxide and (+)-pulegone, are similar in terms of the antimicrobial activity on the tested strains of $S$. aureus and C. albicans.

All of the products present antimocrobial potential with antibacterial activity for $S$. aureus ATCC 25923 and antifungal activity for C. albicans ATCC 76645 .

Limonene oxide and carvone epoxide were the substances which presented the smallest antimicrobial potentials.

None of the products showed antimicrobial activity for the strains of E. coli ATCC 25922 and $P$. aeruginosa ATCC 27853, Gram negative bacteria.

\section{ACKNOWLEDGEMENTS} CAPES-PQI.

Financial support from CNPq, RENORBIO,

\section{REFERENCES}

Agostini F, Santos ACA, Rossato M, Pansera MR, Zattera F, Wasum R, Serafini LA 2005. Estudo do óleo essencial de algumas espécies do gênero Baccharis (Asteraceae) do sul do Brasil. Rev Bras Farmacogn 15: 215-220.

Bauer AW, Kirby WMM, Sherris JC, Turck M 1966. Antibiotic susceptibility testing by standardized single disc method. Am J Clin Patol 45: 493-496.

Benoudia A, Hassar M, Benjilali B 1988. Les propriétés antiséptiques des huiles essentialles in vitro, testées contre des germes pathogenes hospitaliers. Fitoterapia 59: 115-119.

Bertini LM, Pereira AF, Oliveira CLL, Menezes EA, Morais SM, Cunha FA, Cavalcanti, ESB 2005. Perfil de sensibilidade de bactérias frente a óleos essenciais de algumas plantas do nordeste do Brasil. Infarma 17: 80-83.

Bieski IG. 2005. Plantas medicinais e aromáticas no sistema único de saúde da região sul de Cuiabá-MT. Monografia, Universidade Federal de Lavras, MG, 92p.

Carson CF, Cookson BD, Farrelly HD, Riley TV 1995. Susceptibility of methicillin-resistant Staphylococcus aureus to essential oil of Melaleuca alternifolia. J Antimicrob Chemoter 35: 421-424.

Carson CF, Rilley TV 1995. Antimicrobial activity of the major components of essencial oil of Melaleuca alternifolia. J Bacteriol 78: 264-269.

Carvalho-Filho JLS, Blank AF, Alves PB, Ehlert PAD, Melo AS, Cavalcanti SCH, Arrigoni-Blank MF, Silva-Mann R 2006. Influence of the harvesting time, temperature and drying period on basil (Ocimum basilicum L.) essential oil. Rev Bras Farmacogn 16: 24-30.

Casals JB 1979. Tablet sensibility testing of pathogenic fungi. $J$ Clin Pathol 32: 719-722.

Cowan MM 1999. Plant products as antimicrobial agents. Clin Microbial Rev 564-582.

Drutz DJ 1987. In vitro antifungical susceptibility testing and measurement of levels of antifungical agents in body fluids. Rev Infect Dis 9: 411-415. 
Duarte MCT, Figueira GM, Pereira B, Magalhães PM, Delarmelina C 2004. Atividade antimicrobina de extratos hidroalcoólicos de espécies da coleção de plantas medicinais CPQBA/UNICAMP. Rev Bras Farmacogn 14(Supl. 1): 6-8.

Gobert V, Moja S, Colson M, Taberlet P 2002. Hybridization in the section Mentha (Lamiaceae) inferred from AFLP markers. American J Botany 89: 2017-2023.

Guedes DN, Silva DF, Barbosa-Filho JM, Medeiros IA 2004a. Endothelium-dependent hpotensive and vasorelaxant effects of the essential oil from aerial parts of Mentha x villosa in rats. Phytomedicine 11: 490-497.

Guedes DN, Silva DF, Barbosa-Filho JM, Medeiros IA 2004b. Calcium antagonism and the vasorelaxation of the rat aorta induced by rotundifolone. Braz J Med Biol Res 37: 1881-1887.

Gundidza M 1986. Screening of extracts from Zimbabwean higher plants II: antifungical properties. Fitoterapia 57: 111-114.

Hiruma CA 1993. Estudo químico e farmacológico do óleo essencial das folhas da Mentha x villosa Hudson. Dissertação de Mestrado - LTF/UFPB, 97p.

Hoareau L, Silva EJ 2001. Medicinal plants: a re-emerging health aid. J Biotechnol 2: 123-130.

Katsuhara J 1967. Absolute configuration of pulegone oxide and piperitenone dioxide. J Org Chem 32: 797-799.

Lima, IO, Oliveira RAG, Lima EO, Farias NMP, Souza EL 2006. Atividade antifúngica de óleos essenciais sobre espécies de Candida. Rev Bras Farmacogn 16: 197-201.

Lorenzo D, Paz D, Dellacassa E, Davies P, Vila R, Cañigueral S 2002. Essential oils of Mentha pulegium and Mentha rotundifolia from Uruguay. Braz Arch Biol Technol 45: 519-524.

Maciel MAM, Pinto AC, Veiga VF, Grynberg NF, Echevarria A 2002. Plantas medicinais: a necessidade de estudos multidisciplinares. Ouim Nova 25: 429-438.

Marchese JA, Broetto F, Ming LC, Goto R, Stefanini MB, Galina A, Tedesco AC, Conte C, Miniuk CM, Schurt DA, Sangaletti E, Silva GO, Gomes G, Bertagnolli JA, Francheschi L, Cossa ML, Moraes MRD, Lima PM, Lira R, Costa S 2005. Perfil dos consumidores de plantas medicinais e condimentares do município de Pato Branco (PR). Hortic Bras 22: 332-342.

Matos FJA, Machado MI, Craveiro AA, Barbosa-Filho JM, Alencar JW, Barbosa-Filho JM, Cunha EVL, Hiruma CA 1999. Essential oil of Mentha x villosa Huds. An antiparasitic medicinal herb from Nordestern Brazil. J Essent Oil Res 11: 41-44.

Moellering-Jr RC 2000. Novos desafios no campo das doenças infecciosas In: Patógenos emergentes nas doenças infecciosas: relatório especial hospital practice. Euromédice. Ed. Médicas: 5-7.

Monte FJQ, Oliveira EF, Braz-Filho R 2001. Triterpenóides pentacíclicos de Mentha $x$ villosa: identificação estrutural e atribuição dos deslocamentos químicos dos átomos de hidrogênio e carbono. Quim Nova 24: 491-500.

Mounchid K, Bourjilat F, Dersi N, Aboussaouira T, Rachidai A, Tantaoui-Elaraki M, Alaoui-ismaili 2005. The susceptibility of Escherichia coli strains to essential oils of Rosmarinus officinalis and Eucalyptus globules. Afric J Biotechn 4: 1175-1176.

Odds FC 1989. Antifungal activity of saperconazole (R. 66905) in vitro. J Antimicrob Chemoter 24: 533-537.

Ohno T, Kita M, Yamaoka Y, Imamura S, Yamamoto SM, Kodama T, Kashima K, Imanishi J 2003. Antimicrobial activity of essential oils against Helicobacter pylori. Helicobacter 8: 207-215.

Oliveira RAG, Lima EO, Vieira WL, Freire KRL, Trajano VN, Lima, IO, Souza EL, Toledo MS, Silva-Filho RN 2006. Estudo da interferência de óleos essenciais sobre a atividade de alguns antibióticos usados na clínica. Rev Bras Farmacogn 16: 77-82.

Oumzil H, Ghoulami S, Rhajaoni M, Ilidrissi A, Fkih-Tetouani S, Faid M, Benjouad A 2002. Antibacterial and antifungal activity os essential oils of Mentha suaveolens. Phytother Res 16: 727-731.

Plempel M, Berg D, Buchel DB, Abbink D 1986. test methods for antifungal agents - a critical review. Mycosen, 30: 28-34.

Potzernheim MCL, Bizzo HR, Vieira RF 2006. Análise dos óleos essenciais de três espécies de Piper coletadas na região do Distrito Federal (Cerrado) e comparação com óleos de plantas procedentes da região de Paraty, RJ (Mata Atlântica). Rev Bras Farmacogn 16: 246-251.

Santos RB, Brocksom TJ, Brocksom U 1997. A convenient deoxygenation of $\alpha, \beta$ - epoxy ketones to enones. Tetrahedron Lett 38: 745-748.

Sartoratto A, Machado ALM, Delarmelina C, Figueira GM, Duarte MCT, Rehder VL 2004. Composition and antimicrobial activity of essential oils from aromatic plants used in Brazil. Braz J Mricobiol 35: $275-280$.

Seidl PR 2002. Pharmaceuticals from natural products: current trends. An Acad Bras Cienc 74: 145-150.

Silva-Santos A, Antunes AMS, Bizzo HR, D'Avila CA, SouzaSantos LC 2004. The application of essential oils and terpenics/terpenoids compounds in the fields of pharmaceutic and cosmetic through the knowledge registered in patents. Rev Bras Farmacogn 14(Supl. 1): 48-50.

Thomas AF, Bessiere Y 1989. Limonene. Nat Prod Rep 6: 291309.

Trabulsi LR, Altherthum F, Gompertz OF, Candeias JAN 1999. Microbiologia, $3^{\mathrm{a}}$ ed, Atheneu, 215-228.

Wasicky R 1963. Uma modificação do aparelho Clevenger para a extração do óleo essencial. Rev Fac Farm Bioq SP 1: 77-81. 